\title{
Burial crypts in solid rock - \\ a geophysical case study of a small church with a unique polychrome in Szydłów (S Poland)
}

\author{
Artur Zieliński ${ }^{1}$, Mikołaj Łyskowski ${ }^{2}$ Ewelina Mazurkiewicz ${ }^{3}$, \\ Kinga Wiktoria Lubarska ${ }^{4}$ \\ ${ }^{1}$ Jan Kochanowski University in Kielce, Faculty of Mathematics and Natural Sciences; \\ ul. Świętokrzyska 15, 25-406 Kielce, Poland; e-mail: aziel@ujk.kielce.pl; ORCID ID: 0000-0003-1672-7776 \\ ${ }^{2}$ AGH University of Science and Technology; al. A. Mickiewicza 30,30-059 Krakow, Poland; e-mail: mikilys@agh.edu.pl; \\ ORCID ID: 0000-0001-8613-8884 \\ ${ }^{3}$ AGH University of Science and Technology, Faculty of Geology, Geophysics and Environment Protection; \\ al. A. Mickiewicza 30,30-059 Krakow, Poland; e-mail:ewemazurkiewicz@gmail.com \\ ${ }^{4}$ Academy of Fine Arts in Warsaw, Faculty of Conservation and Restoration of Works of Art; \\ Wybrzeże Kościuszkowskie 37, 00-379 Warszawa, Poland; e-mail: kinga@asp.waw.pl
}

(C) 2019 Authors. This is an open access publication, which can be used, distributed and reproduced in any medium according to the Creative Commons CC-BY 4.0 License requiring that the original work has been properly cited.

Received: 19 December 2018; accepted: 13 April 2019; first published online: 3 June 2019

\begin{abstract}
Lesser Poland (Małopolska) is a historic region of Poland. The presented case study was undertaken in the All Saints' Church in the town of Szydłów, in which conservation and restoration works were carried out to preserve Gothic wall paintings by identifying and eliminating the causes of their degradation, and these efforts were supported by geophysical surveying. The conducted studies constitute a step not only to determine the age of the construction of the Szydłów temple, but also to improve knowledge of medieval architecture and mural paintings in Lesser Poland. The geophysical research with application of GPR (Ground Penetrating Radar) helped to locate previously unknown structures under the temple floor. This survey indicated four, possibly connected, structural objects clearly visible in GPR profiles. Carried out works confirmed that anomalies visible on radargrams mark two crypts. This discovery of the hidden construction elements emphasizes and strengthens the earlier suppositions of the unique character of this temple.
\end{abstract}

Keywords: Szydłów, All Saints’ Church, GPR, wall polychrome, crypts

\section{INTRODUCTION}

Lesser Poland is a historic region of Poland, which was particularly significant during the formation of Polish statehood. The aim of this study was to increase the level of knowledge about the construction and development of the medieval church in Szydłów. A case study took place in the most precious monument in the town, the All Saints' Church, during conservation, restoration and geophysical surveying works. The geophysical prospection with the use of the Ground Penetrating Radar (GPR) method helped to locate structures resembling crypts, which were discovered during measurements. Earlier information about their existence had not been extant. The investigation was carried out as a continuation of the restoration work on the wall paintings, which revealed that the church is older than it was assumed and reinforcing its value as an archaeological object. 


\section{THE OBJECT OF THE RESEARCH}

Szydłów is currently a small town located in the Mid-Poland Uplands, on Lesser Poland Uplands (Kondracki 2002). It is characterized by a fortified landscape, which is unique on a European scale (Myczkowski 2006). The settlement was established in the region where the influences of various tribal groups overlapped and, in turn, this fact contributed to laying the foundations of the Polish state. The location of this resort took advantage on one hand of the existence of the Vistula trade route, running from Krakow and Wiślica via Sandomierz to Eastern Europe. On the other hand, it enjoyed a peripheral position between the Krakow and Sandomierz Lands and took advantage of the assets of the local environment.

These factors contributed to the rapid development of settlements belonging to the princes of Krakow and resulted in "colonization on the German Law" probably as early as the $13^{\text {th }}$ century AD. This was recorded in the document of King Władysław Łokietek (Ladislaus I the Elbow-High) in $1329 \mathrm{AD}$, when the town was chartered. A particularly dynamic period of growth was initiated during the reign of King Kazimierz Wielki (Casimir the Great) (Guerquin 1984, Kajzer 2002). Then, ca. 1350-1355 AD the castle was expanded, and the town strengthened with a defensive wall. A parish church was also built, dedicated to Saint Władysław, and, apart from that, there was a number of other buildings erected, thanks to the massive use of the surrounding rock materials, in particular detrital limestone.

The oldest and the most valuable monument in Szydłów is the All Saints' Church. It is located outside the city walls, near the Krakowska Gate, on a hill that descends steeply towards the Ciekąca River valley (Fig. 1). Scholars claim that the church is from the $14^{\text {th }}-15^{\text {th }}$ century AD (Wójcik 1869, Żukowski 1947, Kutrzebianka 1957, Łoziński 1957, Madurowicz-Urbańska 1968, Mroczko \& Arszyński 1995). However, K. Stronczyński, a well-known researcher of monuments, links the location of Szydlów and the foundation of the church of All Saints with the Duke Kazimierz Sprawiedliwy (Casimir the Just). He pinpoints the erection of the building to 1190 AD. Most likely, Stronczyński derived his knowledge from the rich archives of the city that were later burned during fires (Chlebowski 1892, Kowalczyk 2009: 118, 235, Guttmeyer 2010: 106, 109, 312-315). The age postulated by Stronczyński may be confirmed by the fact that Szydłów was mentioned as early as in $1191 \mathrm{AD}$ by the documents of Sandomierz Collegiate (Maszczyński 1996). Therefore, a parish probably existed at that time and the All Saints' Church could well have been its seat since it is the oldest church in Szydłów.

The church is situated on a hill, which in turn is a part of a wider area of hilly terrain, the varied relief of which is carved in Sarmatian detrital limestone covered by a thin layer of rendzina soil. The area is geographically located in the contact zone between Świętokrzyskie (Holy Cross) Mountains and Nida Trough (comp. Kondracki 2002). The Miocene carbonate rocks of the Carpathian Foredeep are typical geological formations outcropping in this region (Zieliński et al. 2016).

The current building of the church is compact - about $17.5 \mathrm{~m}$ long and $9 \mathrm{~m}$ wide. It is a single nave sacral object. Its original shape is based on the medieval block - probably Romanesque (Fig. 2A). This statement can be based on architectural features of the church - i.e. a compact form typical of rural parish churches, which is also characterized by chancel, in a clearly separated rectangular shape, slightly narrower than the nave. In all likelihood, a sacristy was added (from the north side) and a porch (from the west side) in the $17^{\text {th }}$ century. The church is small and was built of Miocene organogenic limestone blocks bonded with lime mortar. Windows and door joinery casings are made of sandstone. Over the centuries, the church has been renovated, therefore some elements are made of brick. The church, a one-nave orientated with a separate part of a rectangular presbytery, has both nave and chancel covered with gable roofs and shingle. Characteristic features of this building are the corner buttresses. The doorways and windows are topped with pointed arch closure. The building's doors are placed: main - from the west, side - from the south, internal - between the presbytery and the sacristy. Most of the windows are finished with an ogive closure - the exception is one of the windows on the south wall of the nave (closer to the western wall), completed with a semi arch (Lubarska 2013). 


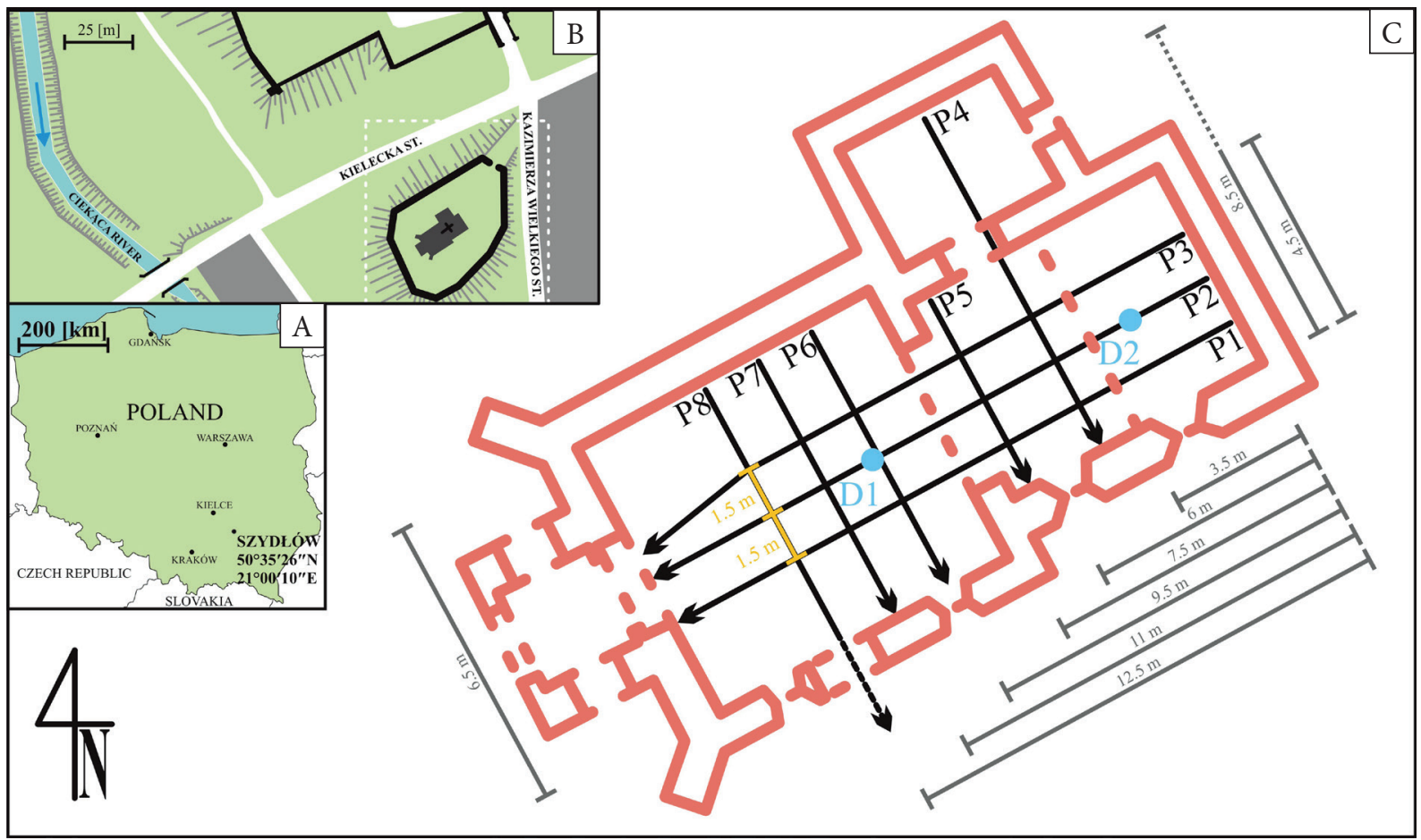

Fig. 1. Location of the study area on the map of Poland (A). Map of the surroundings of the sacred object (B). A schematic plan of the Church of All Saints with the system of measuring GPR profiles $(C)$
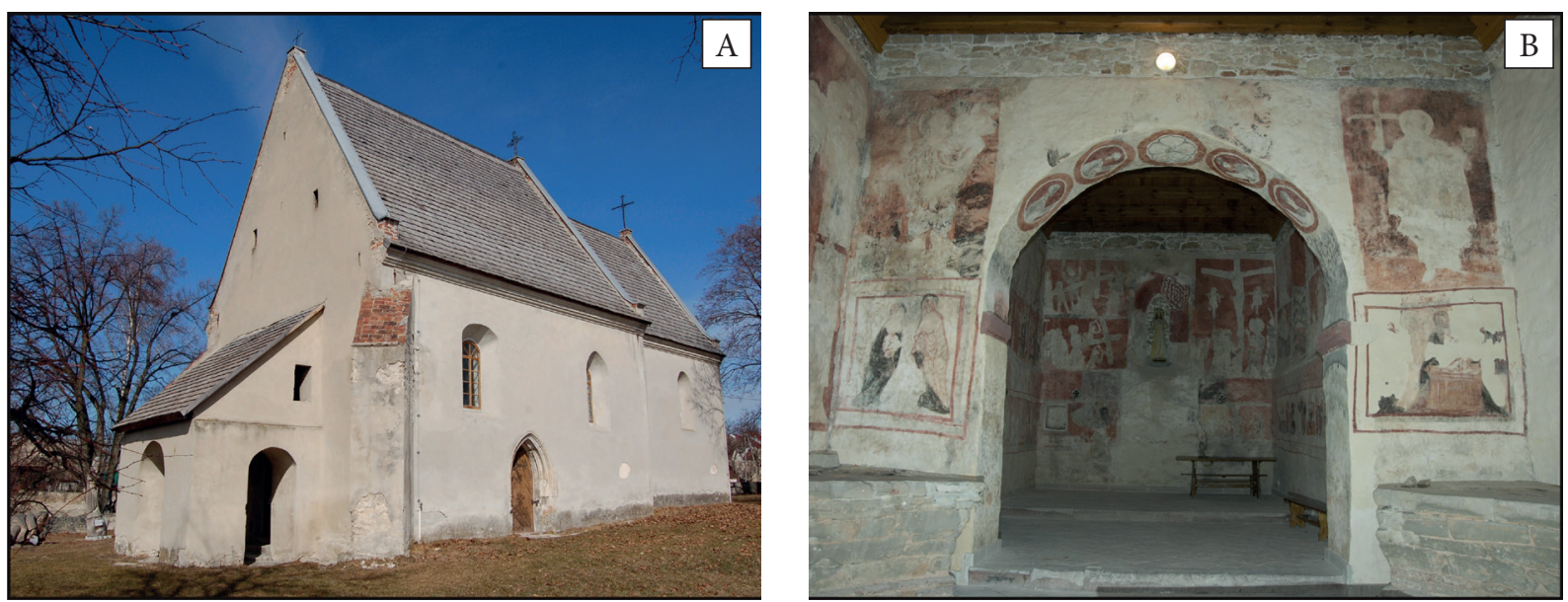

Fig. 2. View from the southern side of the Church of All Saints (photo by K.W. Lubarska) (A). View of the presbytery and the chancel arch murals, seen from the side of the nave (photo by R. Stasiuk) (B)

It is an interesting fact that all of the walls of this small temple are covered with characteristic undulating sand-lime medieval plasters decorated with figural and ornamental wall paintings, discovered by chance in 1944 , after a fire.

Interestingly, the paintings discovered during the maintenance of the northern wall of the nave seem to be much older than previously established. Until now, art historians dated the murals of Szydlów from $1370 \mathrm{AD}$ to the mid- $15^{\text {th }}$ century (Kornecki \& Małkiewiczówna 1984: 16, 45, 48, 66, Karłowska-Kamzowa 1984:209). They were badly damaged and mostly unreadable before the maintenance works. Carried out in the years 1999-2014, a comprehensive 
conservation and restoration works were done by the conservation team of Andrzej Łojszyczyk and Kinga Wiktoria Lubarska. The task of the conservators was carried out according to the rules of the ethics of conservation to maximally preserve the original character of the polychrome (wall paintings). This was difficult since, due to the minimal merging of the composition, it was necessary to bring out the content and form of the remains of a Gothic painting so that it was clear to each recipient. In general, the wall polychromes of the All Saints' Church in Szydłów were akin to a "Bible Pauperum", acting as a visual tool to teach simple, illiterate people through the paintings, enabling them to know "Eternal Truths", and making them reflect on the meaning of human life, teaching and directing their thoughts towards God. Painted decorations are placed in horizontally running zones. There are paintings in the lower part of the walls of the chancel, below offsets, coming from $1370 \mathrm{AD}$. In the church there are also friezes with two cycles. First, the frieze of "Seven Joys of Blessed Virgin Mary" - on the southern, and a second on the northern wall which presents a series of "Seven Deadly Sins" (Lubarska 2011, 2013).

The chancel arch (Fig. 2B) consists of four medallions probably depicting "prophets" holding rolls of the Scriptures, and also decorative rosette in the middle of the arch (Lubarska 2011, 2013). There are four squares of various sizes with figural decoration on both walls adjacent to the arch: "St. Christopher carrying the baby Jesus on his shoulder", the scene of "Visitation", "the Figure of a Saint" (unidentified), and "Sacrifice of the Lord Jesus". The rest of mural decorations contain among others "Passion Cycle", scene of "the Last Judgment", picture of "St. Michael the Archangel weighing souls" and dozens of consecration candle holders (pl. zacheuszki).

Given that the temple has some Romanesque characteristics, it cannot be excluded that the history of this monument is older than currently believed. The fact is that the early medieval part of Lesser Poland region provides an extremely interesting picture of cultural changes, which makes it a valuable area of research (Buko 2011). Due to the still weak recognition of the oldest history of Szydłów, the authors undertook a geophysical survey inside the All Saints' Church.

\section{GEOPHYSICAL RESEARCH METHODS}

In areas of karst formations, many geophysical methods are used, starting with electrical resistivity tomography (ERT) (e.g. Epting et al. 2009), through gravimetric measurements measuring the intensity change of the gravity field strength, ending with the GPR method (e.g. Chamberlain et al. 2000, El-Quady et al. 2005). The last-mentioned surveying method has another common use. It is a precise tool for crypt and grave detection in churches (e.g. Conyers 2012, Panisova et al. 2013, Karczewski et al. 2017, Strzępowicz et al. 2018) and as a result the authors decided to utilize it in this case study. Additionally, given the nature of the place (a historical treasure), and the terrain conditions (limited space), the method chosen by the authors was more than appropriate. Non-invasive, rapid, precise and high-resolution measurements resulted in obtaining results, which were of satisfactory quality.

During the reconnaissance work, the authors used a GPR, which is a geophysical device used for measuring the near-surface part of the geological medium. It utilizes the phenomenon of electromagnetic wave propagation, which, during the propagation process, is subjected to reflection, refraction, attenuation and dispersion. Due to the characteristics of the object, in order to carry out the measurements, a GPR model ProEx of MALA Geoscience Company was used, supplied with shielded antenna at the frequency of $500 \mathrm{MHz}$. The choice of equipment parameters was associated with the expected depth of penetration, satisfactory resolution and the physical properties of the ground. The distance measurement was held on the basis of an odometer. The research experience of the authors allowed the optimal selection of measurement parameters. It was decided to use a measuring step of $0.025 \mathrm{~m}, 8$ times trace stacking, time window about $311 \mathrm{~ns}$ and signal sampling at the level of $5306 \mathrm{MHz}$. There were 8 GPR-profiles taken altogether, with the total length of over $100 \mathrm{~m}$ (Fig. 1C). Geophysical images obtained by a GPR survey of a geological medium are called radargrams. These are graphs consisting of a number of individual traces. The vertical axis represents an electromagnetic wave double 
propagation time in the medium. The horizontal axis indicates the distance covered in the measurement profile (Annan 2001). Before the presentation, radargrams are subjected to processing which is based on the ratio increase between useful information and noise. In this process the raw data were transformed using numerical transformations in a dedicated for Microsoft Windows operating system ReflexW software. Those were:

- static corrections - "move start-time" which is hand typed, fixed value of time (in nanoseconds), which is the time of the first signal occurrence in the given scan, next "time cut" that deletes data above a given time and at the end "static correction" which allows to input on radargram the "topography" of terrain such as stairs steps;

- a number of filters operating on traces in order to remove the distortion of the signal like: "subtract-DC-shift" where the program calculates mean value ("DC-value") for the given time range of the given scan and subtracts this value from all data values of the scan and "substract-mean (dewow)" which creates within the moving time window (along $\mathrm{Z}$ axis) a mean value and subtracts the value from the actual data value;

- frequency filters - "band-pass-butterworth" which performs a band-pass filtering that passes frequencies within a certain range on the given time-domain;

- amplitude strengthening - "gain function" strengthening time-dependent multiplayer applied to enhance the farther reflexes;

- or eventually filters operating in a specific area to "smooth out" the image like "stack traces" which averages a given number of traces on radargram (ReflexW... 2010).

In order to calculate the depth scale, the program accomplished the time-depth conversion on the basis of a certain speed of electromagnetic wave propagation in the examined medium (Łyskowski \& Mazurek 2013). The authors carried out WARR profiling (Wide Angle Reflection-Refraction) and adopted the electromagnetic wave propagation velocity of $0.18 \mathrm{~m}^{1} \cdot \mathrm{ns}^{-1}$, which is above the tabular values of EM wave velocity in limestone, but still suitable (OYO 1988, Annan 2001).

\section{RESULTS}

In the profiles $\mathrm{P} 1$ and $\mathrm{P} 3$ (Fig. 3A, C), between 8 and $10 \mathrm{~m}$, an anomaly appears at a depth of about $1 \mathrm{~m}$, the origin of which is most likely the occurrence of an empty space. Perhaps it is a crypt or the remnants of the earlier church. A less clear reflection than described above appears in profile P2 (Fig. 3B) between 9 and $12 \mathrm{~m}$ at the same depth. It is probably a structure filled with some material. Contacting to this anomaly on profile $\mathrm{P} 2$ between 11 and $14 \mathrm{~m}$ at depth about $0.6 \mathrm{~m}$ appears change on radargram which cannot be clearly interpreted. This GPR profile shows the movement of the object and a distorted image - it is unclear why the deeper anomaly appears with shift in position on profiles $\mathrm{P} 1$ to $\mathrm{P} 3$. In all these cases a ceiling and a bottom horizon can be distinguished, the latter at a depth of about $1.2 \mathrm{~m}$ under the floor surface. It should be noted that there may occur a change of depth measurement of the bottom if the object is only filled with air.

Before drilling works, several original $17^{\text {th }}$ century tiles were removed from the present floor. These were made of gray sandstone and lifting them up posed no problems since they were only loosely placed on the layer. A visual inspection was carried out with the use of small camera inserted through ca. $0.02 \mathrm{~m}$ diameter boreholes, confirming the GPR results and the existence of a filled in crypt. The filling material was sand originating from the weathered detrital limestone - the main rock in the area, and included an admixture of sand and silt with a small addition of gravels. The walls of those crypts are encased with detrital limestone plates. Inspection boreholes also indicated the presence of an older floor carved from detrital limestone with a thickness of approximately $0.08 \mathrm{~m}$. This horizon exists below the sandy layer at a depth of approx. $0.55 \mathrm{~m}$.

The anomalies in profiles $\mathrm{P} 1-\mathrm{P} 3$, between a distance of 1 and $6 \mathrm{~m}$ and at a depth of about $0.6 \mathrm{~m}$ (Fig. 3) under the floor surface (in the chancel part of a church), as well as the perpendicularly running profile P4 (Fig. 4D), document an unknown structure - probably a chamber filled with air, e.g. a crypt. 

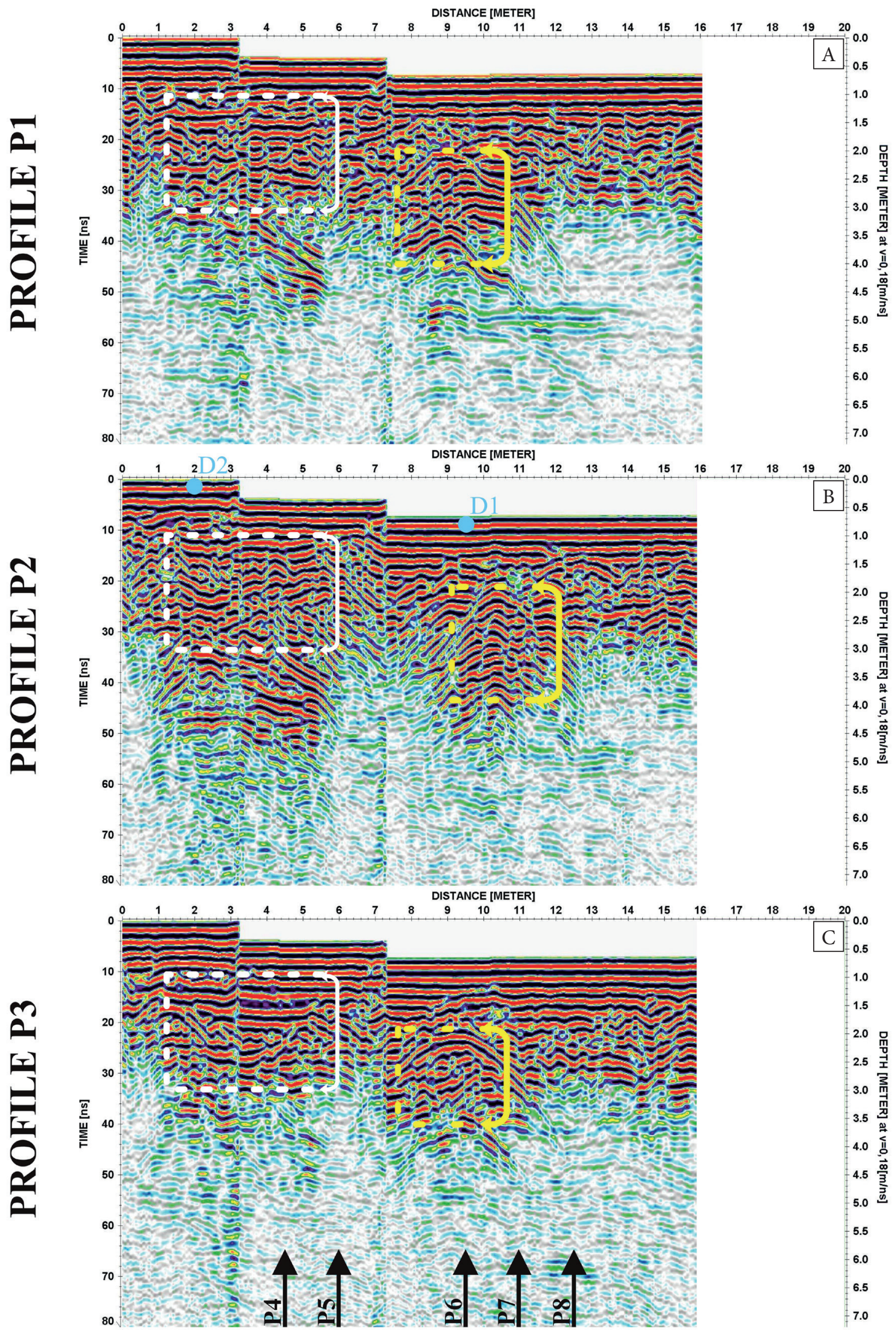

Fig. 3. Three selected radargrams (profiles: $A-P 1, B-P 2, C-P 3)$ with locations of the crypts marked (white - in the chancel; yellow - in the main nave) 
The interpretation was not unequivocal and it was impossible to determine whether it came from an empty structure under the floor, by only analyzing the radargram. The small diameter drilling works carried out (Fig. 4A-C) confirmed that a loose layer of sandy fraction above the anomaly on the geophysical images (Fig. 4D) had a thickness of about $0.5 \mathrm{~m}$. Beneath it, a ceiling vault of a crypt was found with a thickness of several centimeters. This crypt, in contrast to the one described previously which was filled with air, had bones and decayed wood, probably from a coffin, visible at the bottom (Fig. 4). Its bottom was identified as lying at a depth of about $2.15 \mathrm{~m}$ under the floor surface.

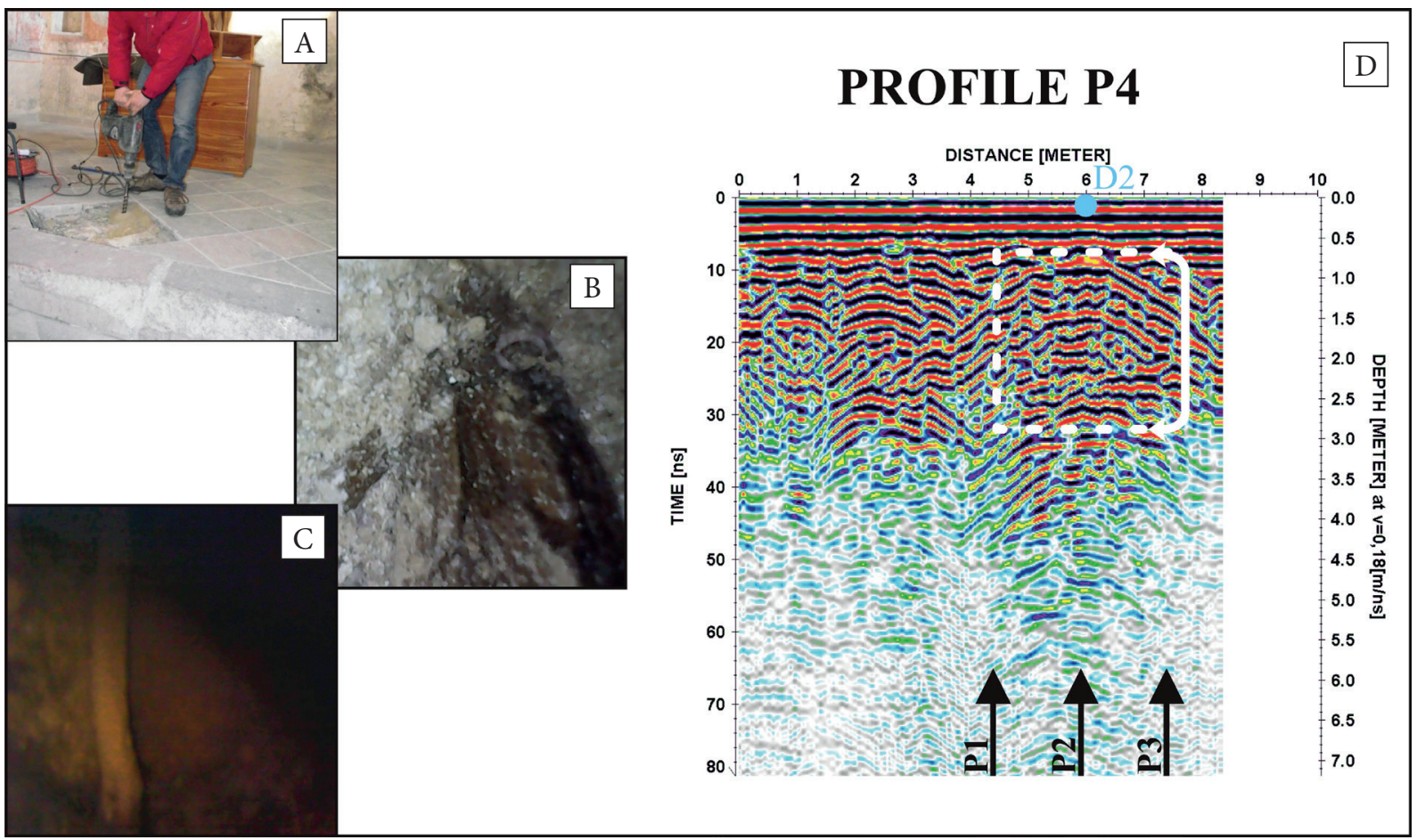

Fig. 4. Photo from inspection drilling works in place D2 above the crypt in the chancel (A). Photo from a microcamera of the crypt in place D2 interior, with dark fragments of a decayed coffin visible on the sand (B). Photo from the crypt in place D2 with visible bone fragments (C). Radargram from profile P4 with the location of the crypt marked (D)

\section{CONCLUSIONS}

The surveys succeeded in documenting the position of previously unknown chambers under the church floor. This case, and many other works carried out with use of geophysical methods (e.g. Leucci 2006, Negri \& Leucci 2006) show their huge potential in the field of archaeological prospection. The surveys enabled the documentation of the two crypts, the existence of which being confirmed by the inspection boreholes in places where geophysical images indicated GPR anomalies. The anomaly in point $\mathrm{D} 2$ that was confirmed in boreholes and is marked by the arched reflection of ceiling. It is significantly wider than in the case of very local anomalies, and on perpendicular profiles the reflections are almost horizontal, ending sharply. Below the ceiling, some weak distortions are visible on the radargram, probably suggesting the presence of some smaller scattering objects.

The conservation and restoration works in the All Saints' Church in Szydłów highlighted its unique character and the geophysical study presented emphasizes and strengthens these earlier suppositions. In addition, it shows that such combination of research methods could support determination of the All Saints' Church construction date, and would improve the knowledge of 
medieval architecture and mural painting in Lesser Poland.

The continuation of research in demarcated areas in the buildings would be crucial to help identify the oldest history of Szydłów. Certainly, further research in places where geophysical anomalies occur could bring significant value in understanding the cultural transformations at play in Early Medieval Lesser Poland.

Authors would like to thank Father Ryszard Piwowarczyk - parson of the parish of St. Władysław in Szydtów and Jan Klamczyński - mayor of Szydłów, and also Janusz Cedro and Andrzej Przychod$n i$ - Antiquities Conservator of Świętokrzyski Region and his deputy - Zbigniew Wojtasik, for their kindness and help. Authors also sincerely thank Mrs. Maria Stachuczy - the Director of the Municipal Cultural Center in Szydłów and Piotr Walczak - plenipotentiary for the promotion of the commune office in Szydłów. Authors would like to thank Artur Komorowski (Terra-Explo group and Stowarzyszenie Speleoklub Beskidzki) and Construction Company ANNA-BUD Sp. Z.O.O. from Bilcza near Kielce for their help during the inspection works. Special thanks are also offered to Prof. Anna Drazkkowska from the Institute of Archaeology at the Nicolaus Copernicus University in Torun and Prof. Barbara Gawdzik - Dean of The Faculty of Mathematics and Natural Sciences at the Jan Kochanowski University in Kielce for their help on the archaeological aspects of this paper. Authors would like to thank the Reviewers for their suggestions, which helped us to improve the manuscript.

Authors declare no conflict of interest in terms of relationship or financial matters.

\section{REFERENCES}

Annan A.P., 2001. Ground Penetrating Radar Workshop Notes. Sensors \& Software Inc., Ontario, Canada.

Buko A., 2011. Archeologia w badaniach wczesnośredniowiecznej Małopolski. [in:] Jastrzębski C. (red.), Szydłów przez stulecia. Monografia Gminy Szydłów, Wyd. Gmina Szydłów, 29-44.

Chamberlain A.T., Sellers W., Proctor C. \& Coard R., 2000. Cave Detection in Limestone using Ground Penetrating Radar. Journal of Archaeological Science, 27, 957-964. DOI: https://doi.org/10.1006/jasc.1999.0525.
Chlebowski B. (red.), 1892. Słownik geograficzny Królestwa Polskiego i innych krajów słowiańskich. Tom 12. Warszawa.

Conyers L.B., 2012. Interpreting Ground-penetrating Radar for Archaeology. Left Coast Press, Walnut Creek, California.

El-Quady G., Hafez M., Abdalla M.A. \& Ushijima K., 2005. Imaging subsurface cavities using geoelectric tomography and ground-penetrating radar. Journal of Cave and Karst Studies, 67, 3, 174-181, [on-line:] https://caves. org/pub/journal/PDF/V67/v67n3-El-Qady.htm [access: 10.12.2018].

Epting J., Huggenberger P. \& Glur L., 2009. Integrated investigations of karst phenomena in urban environments. Engineering Geology, 109, 273-289. DOI: https://doi. org/10.1016/j.enggeo.2009.08.013.

Guerquin B., 1984. Zamki w Polsce. Wyd. 2 popr. „Arkady”, Warszawa.

Guttmejer K. (oprac.), 2010. Kazimierza Stronczyńskiego opisy i widoki zabytków w Królestwie Polskim (1844-1855). T. 2: Gubernia Radomska. Krajowy Ośrodek Badań i Dokumentacji Zabytków, Warszawa.

Kajzer L., 2002. Zamek królewski w Szydłowie w świetle najnowszych badań terenowych. [in:] Antoniewicz M. (red.), Zamki i przestrzeń społeczna w Europie Środkowej $i$ Wschodniej, Warszawa, DiG, 391-409.

Karczewski J., Ortyl Ł. \& Mazurkiewicz E., 2017. Ocena wpływu wybranych parametrów profilowań georadarowych w badaniach podłoża gruntowego na potrzeby budownictwa na przykładzie zrębu Zakrzówka. Przegląd Geologiczny, 65, 796-802.

Karłowska-Kamzowa A. (red.), 1984. Gotyckie malarstwo ścienne w Polsce. Wyd. Naukowe UAM, Poznań.

Kornecki M. \& Małkiewiczówna H., 1984. Małopolska. [in:] Karłowska-Kamzowa A. red.), Gotyckie malarstwo ścienne w Polsce, Wyd. Naukowe UAM, Poznań, 13-78.

Kowalczyk J. (oprac.), 2009. Kazimierza Stronczyńskiego opisy $i$ widoki zabytków w Królestwie Polskim (18441855). T. 1: Ogólne sprawozdanie Delegacji, Krajowy Ośrodek Badań i Dokumentacji Zabytków, Warszawa.

Kondracki J., 2002. Geografia regionalna Polski. Wydawnictwo Naukowe PWN, Warszawa.

Kutrzebianka K. (oprac.), 1957. Powiat buski. [series:] Wolff-Łozińska B. \& Łoziński Z. (red.), Katalog zabytków sztuki w Polsce, t. 3, Województwo kieleckie, z. 1, Państwowy Instytut Sztuki. Dział Inwentaryzacji Zabytków, Warszawa.

Leucci G., 2006. Contribution of Ground Penetrating Radar and Electrical Resistivity Tomography to identify the cavity and fractures under the main Church in Botrugno (Lecce, Italy). Journal of Archaeological Science, 33, 1194-1204. DOI: https://doi.org/10.1016/ j.jas.2005.12.009.

Lubarska K., 2011. Kościół pod wezwaniem Wszystkich Świętych w Szydłowie. [in:] Jastrzębski C. (red.), Szydłów przez stulecia. Monografia Gminy Szydłów, Wyd. Gmina Szydłów, 201-206.

Lubarska K.W., 2013. Kościół pod wezwaniem Wszystkich Świętych w Szydłowie. Zapiski Kazimierzowskie, 11, 59-65. 
Łyskowski M. \& Mazurek E., 2013. Analiza konsekwencji doboru nieodpowiedniej prędkości propagacji fali elektromagnetycznej $\mathrm{w}$ trakcie interpretacji inżynierskich pomiarów metodą georadarową. Logistyka, 4, 330-336, [on-line:] https://www.czasopismologistyka.pl/artykuly-naukowe/send/271-artykuly-na-plycie-cd/3333-artykul [access: 10.12.2018].

Madurowicz-Urbańska H., 1968. Lustracja województwa sandomierskiego 1789. Cz. 3, Powiat wiślicki. [series:] Lustracje dóbr królewskich XVI-XVIII wieku. Małopolska, Materiały Komisji Nauk Historycznych, 14, Wydawnictwo PAN, Zakład Narodowy im. Ossolińskich, Wrocław - Warszawa - Kraków.

Maszczyński T., 1966. Szydłów. Muzeum Świętokrzyskie, Kielce.

Mroczko T. \& Arszyński M. (red.), 1995. Architektura gotycka w Polsce. Cz. 2: Katalog zabytków. IS PAN, Warszawa.

Myczkowski Z., 2006. Szydłów - niezwykły krajobraz warowny w skali Europy. Wiadomości Konserwatorskie, 19 , $38-44$.

Negri S. \& Leucci G., 2006. Geophysical investigation of the Temple of Apollo (Hierapolis, Turkey). Journal of Archaeological Science, 30, 1505-1513. DOI: https://doi. org/10.1016/j.jas.2006.02.003.
OYO, 1988. OYO Georadar I Manual. Oyo Corporation, Tsukuba.

Panisova J., Frastia M., Wunderlich T., Pasteka R. \& Kusnirak D., 2013. Microgravity and Ground-penetrating Radar Investigations of Subsurface Features at the St Catherine's Monastery, Slovakia. Archaeological Prospection, 20, 163-174. DOI: https://doi.org/10.1002/arp.1450.

ReflexW Manual. User Guide, 2010. SandmeierGeo, Karlsruhe, Germany.

Strzępowicz A., Łyskowski M., Ziętek J. \& Tomecka-Suchoń S., 2018. Detection of Unknown Crypts under the Floor in the Holy Trinity Church (Dominican Monastery) in Krakow, Poland. E3S Web of Conferences, 35, art. no. 03006, 1-8. DOI: https://doi.org/10.1051/e3sconf/ 20183503006

Wójcik W., 1869. Miasto Szydłów i ruiny zamku Szydłowskiego. Kłosy: czasopismo ilustrowane, tygodniowe, poświęcone literaturze, nauce i sztuce, 8, 191, 94.

Zieliński A., Mazurkiewicz E. \& Łyskowski M., 2016. GPR mapping of karst formations under a historic building in Szydłów, Poland. Geofizika, 33, 101-111. DOI: https:// doi.org/10.15233/gfz.2016.33.4.

Żukowski J., 1947. Problemy zabytkowe Szydłowa. Odbitka $\mathrm{z}$ „Pamiętnika Kieleckiego”, Kielce. 